\title{
ANALISIS BELANJA DI UPTD BALAI PENGAWASAN DAN SERTIFIKASI MUTU BARANG DINAS PERINDUSTRIAN DAN PERDAGANGAN PROVINSI SULAWESI UTARA MENURUT PERMENDAGRI NOMOR 64 TAHUN 2013
}

\author{
Natalia Manopo ${ }^{1}$, Jenny Morasa $^{2}$, Lidia M. Mawikere $^{3}$ \\ ${ }^{1,2,3}$ Fakultas Ekonomi dan Bisnis, Jurusan Akuntansi, Universitas Sam Ratulangi, Jl. Kampus Bahu, Manado, \\ 95115, Indonesia \\ E-mail : nataliamanopo80@gmail.com
}

\begin{abstract}
Expenditure, in Statement of Budget Realization is an important component that attracts public attention. This is because the public as a public fund through the local taxes they pay is concerned to know whether the funds have been used properly, efficiently, effectively, and oriented to the public interest. Local Expenditure also reflects the policies of local government and the direction of regional development.Mahmudi (2016: 153). The purpose of this study is to determine whether the expenditure on UPTD (Technical Implementing Service Unit) Balai Pengawasan and Sertifikai Mutu Barang of Industry and Commerce Officeof North Sulawesi in accordance with Regulation of Minister of Home Affairs Number 64 of 2013. The research method used is qualitative research method. The results showed that the recognition and measurement of official travel expenditure both domestic region and foreign at UPTD (Technical Implementing Service Unit) ) Balai Pengawasan and Sertifikai Mutu Barang of Industry and Commerce Office of North Sulawesi has been in accordance with Regulation of Minister of Home Affairs Number 64 of 2013 but Reporting of official travel expenditures on the Statement of Budget Realization at the UPTD (Technical Implementing Service Unit) ) Balai Pengawasan and Sertifikai Mutu Barang of Industry and Commerce Office of North Sulawesi there is a difference between Regulation of Minister of Home Affairs Number 64 of 2013 with the implementation in terms of classification of Chart of Account (CoA).
\end{abstract}

Keywords : Expenditure, Regulation of Minister of Home Affairs Number 64 of 2013

\section{PENDAHULUAN}

Kesadaran masyarakat yang meningkat terhadap penyelenggaraan administrasi publik memicu timbulnya gejolak yang berakar pada ketidakpuasan.Tuntutan yang semakin tinggi diajukan terhadap pertanggungjawaban yang diberikan oleh penyelenggara Negara atas kepercayaan yang diamanatkan kepada mereka. Dengan kata lain, kinerja instansi pemerintah kini lebih banyak mendapat sorotan, karena masyarakat mulai mempertanyakan manfaat yang mereka peroleh atas pelayanan instansi pemerintah. Mahsun (2015:142).

Salah satu misi pemerintahan Indonesia saat ini adalah mewujudkan pemerintahan yang bersih.Upaya konkrit dalam mewujudkan transparansi dan akuntabilitas di lingkungan pemerintah (daerah) mengharuskan setiap pengelola keuangan daerah untuk menyampaikan laporan pertanggungjawaban pengelolaan keuangan daerah. Tahun 2005 pemerintah telah menerbitkan Peraturan Pemerintah (PP) Nomor 24 Tahun 2005 tentang Standar Akuntansi Pemerintahan (SAP).Peraturan tersebut mengatur akuntansi berbasis kas menuju akrual (Cash towards Accrual), dan merupakan PP transisi karena UU Keuangan Negara dan Perbendaharaan Negara mengamanatkan pengakuan dan pengukuran pendapatan dan belanja basis akrual.Tahun 2010, Standar Akuntansi Pemerintahan (SAP) berbasis akrual tuntas disusun Komite Standar Akuntansi Pemerintahan (KSAP) dan ditetapkan sebagai Peraturan Pemerintah dalam PP Nomor 71 Tahun 2010.Implementasi dari peraturan tersebut, Laporan Keuangan Pemerintah Pusat maupun Daerah secara bertahap didorong untuk menerapkan 
akuntansi berbasis akrual.Paling lambat tahun 2015, seluruh laporan keuangan daerah sudah menerapkan SAP berbasis akrual.

Untuk melaksanakan keteentuan PP Nomor 71 tahun 2010 tentang Standar Akuntansi Pemerintahan, perlu ditetapkan Peraturan Menteri Dalam Negeri Republik Indonesia tentang Penerapan Standar Akuntansi Pemerintahan Berbasis Akrual Pada Pemerintah Daerah yaitu Permendagri Nomor 64 Tahun 2013. SAP berbasis akrual adalah SAP yang mengakui pendapatan, beban, asset, utang, dan ekuitas dalam pelaporan finansial berbasis akrual, serta mengakui pendapatan, belanja dan pembiayaan dalam pelaporan pelaksanaan anggaran berdasarkan basis yang ditetapkan dalam APBD.

Belanja dalam Laporan Realisasi Anggaran merupakan komponen penting yang mengundang perhatian publik. Hal ini disebabkan karena masyarakat sebagai pemberi dana publik (public fund) melalui pajak daerah yang mereka bayarkan berkepentingan untuk mengetahui apakah dana tersebut telah digunakan dengan semestinya, efisien, efektif, dan berorientasi pada kepentingan publik. Mahmudi (2016:153). Dalam Permendagri Nomor 64 Tahun 2013, belanja adalah semua pengeluaran dari Rekening Kas Umum Daerah yang mengurangi saldo anggaran lebih dalam periode tahun anggaran bersangkutan yang tidak akan diperoleh pembayarannya kembali oleh Pemerintah Daerah.

Setelah dibelanjakan dan dilaporkan dalam Laporan Realisasi Anggaran analisis terhadap belanja ini pun mutlak harus dilakukan untuk dijadikan dasar evaluasi, koreksi, dan perbaikan ke depan. Analisis belanja daerah sangat penting dilakukan untuk mengevaluasi apakah pemerintah daerah telah menggunakan APBD secara ekonomis, efisien, dan efektif (value for money). Sejauh mana pemerintah daerah telah melakukan efisiensi anggaran, menghindari pengeluaran yang tidak perlu dan pengeluaran yang tidak tepat sasaran.Mahmudi (2015:154).

Secara normatif, anggaran belanja merupakan batas tertinggi pengeluaran yang boleh dilakukan.Kinerja pemerintah daerah dinilai baik apabila pemerintah daerah mampu melakukan efisiensi belanja.Sebaliknya jika realisasi belanja lebihbesar dari jumlah yang dianggarkan maka hal itu mengindikasikan adanya kinerja anggaran yang kurang baik.

\section{TINJAUAN PUSTAKA}

\subsection{Akuntansi}

Akuntansi dapat didefinisikan sebagai sebuah sistem informasi yang memberikan laporan kepada para pengguna informasi akuntansi atau kepada pihak-pihak yang memiliki kepentingan (stakeholdersi) terhadap hasil kinerja dan kondisi keuangan perusahaan.Akuntansi juga sering dianggap sebagai bahasa bisnis, dimana informasi bisnis dikomunikasikan kepada stakeholdersmelalui laporan akuntansi.Mula-mula sebuah transaksi bisnisakan diidentifikasi (dianalisis), dicatat, dan barulah dilaporkan lewat laporan akuntansi yang merupakan media komunikasi informasi akuntansi. Herry (2017:6).

\subsection{Akuntansi Sektor Publik}

\subsubsection{Pengertian Akuntansi Sektor Publik}

Akuntansi adalah suatu aktivitas jasa yang terdiri dari mencatat, mengklasifikasikan, dan melaporkan kejadian atau transaksi ekonomi yang akhirnya akan menghasilkan suatu informasi keuangan yang akan dibutuhkan oleh pihak-pihak tertentu untuk pengambilan keputusan. Sektor publik adalah semua yang berhubungan dengan kepentingan publik dan tentang penyediaan barang dan jasa yang ditujukan untuk publik, dibayarkan melalui pajak dan pendapatan Negara lainnya yang sudah diatur dalam hukum. Sujarweni (2015:1). Secara sederhana Renyowijoyo (2013:1) mendefinisikan akuntansi sektor publik adalah sistem akuntansi yang dipakai oleh lembaga-lembaga publik sebagai salah satu alat pertanggung jawaban kepada publik. 


\subsection{Akuntansi Pemerintahan}

Akuntansi Pemerintahan adalah akuntansi yang bersangkutan dengan bidang keuangan Negara, dari anggaran sampai dengan pelaksanaan dan pelaporannya, termasuk segala pengaruh yang ditimbulkannya. Sujarweni (2015:18). Dalam Akuntasi Pemerintahan, data akuntasi digunakan untuk memberikan informasi mengenai transaksi ekonomi dan keuangan pemerintah kepada pihak eksekutif, legislatif, yudikatif dan masyarakat. Akuntansi pemerintah dibedakan atas akuntansi pemerintah pusat dan akuntasi pemerintah daerah yang sering disebut dengan akuntansi keuangan daerah.Akuntansipemerintah daerah terdiri dari akuntasi pemerintah provinsi dan akuntansi pemerintah kabupaten/kota. Erlina, et al (2013:2)

\subsection{Anggaran}

\subsubsection{Pengertian Anggaran}

Menurut Mahsun, et al (2015:65) anggaran merupakan pernyataan mengenai estimasi kinerja yang akan dicapai oleh suatu organisasi dalam periode tertentu yang dinyatakan dalam ukuran moneter. Dalam organisasi sektor publik anggaran merupakan instrumen akuntabilitas atas pengelolaan dana publik dan pelaksanaan program-program yang dibiayai dengan uang publik. Penganggaran dalam organisasi sektor publik merupakan aktivitas yang penting karena keterkaitan dengan proses penentuan aksi dana untuk setiap program maupun aktivitas. Tiga aspek yang harus tercakup dalam anggaran sektor publik meliputi aspek perecanaan, aspek pengendalian dan aspek akuntabilitas publik.

\subsection{Belanja}

\subsubsection{Pengertian Belanja}

Peraturan Menteri Dalam Negeri Republik Indonesia Nomor 64 Tahun 2013 pasal 1 ayat 29, yang dimaksud dengan belanja adalah semua pengeluaran dari Rekening Kas Umum Daerah yang mengurangi Saldo Anggaran Lebih dalam periode tahun anggaran bersangkutan yang tidak akan diperoleh pembayarannya kembali oleh pemerintah daerah. Siregar (2015:161) juga memaparkan belanja adalah semua pengeluaran yang dilakukan oleh bendaharawan umum pemerintah yang mengurangi saldo anggaran lebih dalam periode tahun anggaran bersangkutan yang tidak akan diperoleh pembayarannya kembali oleh pemerintah, Istilah "semua pengeluaran" mengacu pada semua kas yang dikeluarkan untuk memperoleh pendapatan atau pengeluaran untuk modal dan pembayaran utang. Belanja merupakan istilah yang digunakan untuk pengeluaran pada laporan realisasi anggaran.Belanja dicatat berdasarkan basis kas.

\subsubsection{Klasifikasi Belanja}

PSAP No. 2 Paragraf 34 menyatakan bahwa belanja diklasifikasikan menrut klasifikasi ekonomi (jenis belanja), organisasi dan fungsi.Klasifikasi ekonomi merupakan pengelompokkan belanja yang didasarkan pada jenis belanja untuk melaksanakan suatu aktivitas.Klasifikasi ekonomi untuk pemerintah pusat yaitu belanja pegawai, belanja barang, belanja modal, bunga, subsidi, hibah, bantuan sosial, dan belanja tak terduga. Erlina, et al (2015:154). Klasifikasi belanja untuk tujuan pelaporan keuangan menurut PSAP No. 2 Paragraf 36-40 dalam Erlina, et al (2015:154) dikelompokan menjadi :

1. Belanja Operasi

2. Belanja Modal

3. Belanja Lain-Lain/Belanja Tak terduga

4. Transfer Keluar 


\subsubsection{Pengakuan Belanja}

Siregar (2015:174) menjelaskan bahwa pengakuan merupakan penentuan terpenuhinya kriteria pencatatan suatu transaksi.Suatu unsur diakui berarti unsur tersebut menjadi bagian yang melengkapi unsur asset, kewajiban, ekuitas, pendapatan LRA, belanja, pembiayaan, pendapatan LO, beban yang pada laporan keuangan.

\subsubsection{Pengukuran Belanja}

Pengakuan menurut Siregar (2015:175) adalah proses penetapan nilai uang untuk mengakui dan memasukkan setiap pos dalam laporan keuangan. Pengukuran menggambarkan penentuan besarnya jumlah dalam laporan keuangan.Belanja diakui sebesar jumlah pengeluaran kas yang keluar dari rekening kas umum atau rekening bendahara pengeluaran berdasarkan azas bruto. Menurut Permendagri No 64 Tahun 2013, akuntansi belanja dilaksanakan berdasarkan azas bruto dan diukur berdasarkan nilai nominal yang dikeluarkan dan tercantum dalam dokumen pengeluaran yang sah. Halim (2014:109) menjelaskan pengukuran belanja menggunakan mata uang rupiah.

\subsubsection{Prosedur Akuntasi Belanja SKPD}

Menurut Permendagri nomor 64 tahun 2013 fungsi-fungsi yang terkait dengan prosedur akuntasi belanja SKPD adalah :

1. Kuasa Bendahara Umum Daerah (BUD)

2. Pejabat Penatausahaan Keuangan (PPK-SKPD)

3. Pengguna Anggaran/Kuasa Penguna Anggaran.

Dalam Prosedur pembayaran, belanja dikelompokan menjadi dua, yaitu:

a. Belanja Uang Persediaan (UP)/Pergantian Uang (GU)/Tambahan Uang (TU)

b. Belanja langsung (belanja LS). Belanja langsung dikelompokkan menjadi belanja langsung gaji dan belanja langsung nongaji.

\subsection{Penelitian Terdahulu}

Grace Yunita Liando (2016) dalam penelitian berjudul Analisis Kinerja Belanja dalam Laporan Reaslisasi Anggaran (LRA) pada Dinas Pendapatan Pengelolaan Keuangan dan Aset Daerah Kabupaten Kepulauan Sangihe. Hasil penelitian menunjukkan bahwa belanja pada LRA untuk T.A 2011-2014 menunjukkan bahwa kinerja belanja PemKab Kepulauan Sangihe dinilai baik dan terus melakukan perbaikan setiap tahun dalam pemanfaatan realisasi belanja. Pertumbuhan belanja mulai terlihat pada T.A 2013 dan 2014 dibandingkan dengan T.A 2011 dan 2012.

Fransiskus X. W. Katit (2016) dalam penelitian berjudul Analisis Kinerja Belanja Pada Pemerintah Daerah Kabupaten Asmat Provinsi Papua. Hasil penelitian menunjukkan Dari beberapa analisis yang telah dilakukan Pemerintah daerah Kabupaten Asmat Sudah menunjukan hasil yang positif dalam kinerja belanja. Namun pemerintah daerah lebih mempertimbangkan dimana belanja yang di dalamnya mengenai kepentingan umum harus lebih ditingkatkan.

\section{METODE PENELITIAN}

\subsection{Jenis Penelitian}

Penelitian ini menggunakan tipe penelitian naturalistic jika dilihat dari klasifikas penelitian berdasarkan metode. Penelitian ini sering disebut dengan metode kualitatif, yaitu penelitian yang digunakan untuk meneliti pada suatu objek yang alami dengan cara memberi pemaparan terhadap objek tersebut, dan penelitinya berperan sebagai instrument kunci yang akan membuat pemaparan dan penyimpulan. Sujarweni (2014:9). 


\subsection{Tempat dan Waktu Penelitian}

Penelitian berjudul Analisis Belanja Berdasarkan Permendagri Nomor 64 Tahun 2013 pada Dinas Perindustrian dan Perdagangan Provinsi Sulawesi Utara ini dilakukan di Kantor Dinas Perindustrian dan Perdagangan Provinsi Sulawesi Utara. Penelitian ini dimulai pada bulan Juni 2017 sampai bulan Agustus 2017.

\subsection{Prosedur Penelitian}

1. Latar Belakang

2. Rumusan Masalah

3. Tujuan Penelitian

4. Pengumpulan Data

5. Mengumpulkan data yang berhubungan dengan masalah penelitian berupa data primer dan data sekunder.

6. Memperoleh gambaran umum dari objek penelitian secara keseluruhan serta mengetahui permasalahan yang ada

7. Mengelolah data yang ada

8. Menarik kesimpulan dan memberikan saran yang dianggap perlu sebagai perbaikan dalam masalah yang ada.

\subsection{Metode Pengumpulan Data}

\section{Jenis Data}

Menurut Sujarweni (2014:89) data dalam penelitian merupakan sekumpulan informasi yang diperoleh dari lapangan dan digunakan untuk bahan penelitian meliputi data sebagai berikut.Jenis data dapat dibedakan menjadi dua jenis, yaitu:

1. Data kualitatif merupakan data bukan angka yang tidak dapat dilakukan operasi matematika, seperti penambahan, pengurangan, perkalian dan pembagian.

2. Data kuantitatif merupakan data yang berupa angka dan dapat dilakukan berbagai operasi matematika.

Jenis data yang digunakan dalam penelitian ini adalah jenis data kualitatif berupa hasil wawancara dengan pegawai UPTD Balai Pengujian dan Sertifikasi Mutu Barang mengenai prosedur belanja dalam hal ini belanja perjalanan dinas.Selain data kualitatif, juga digunakan data kuantitatif yaitu data dalam Laporan Keuangan UPTD Balai Pengujian dan Sertifikasi Mutu Barang, khususnya Laporan Realisasi Anggaran dengan kode rekening 5.2.2.15 Belanja Perjalanan Dinas.

\section{Sumber Data}

Sumber data adalah subjek dari mana asal data penelitian itu diperoleh. Sujarweni (2014:73). Berdasarkan sumbernya, data dibagi menjadi:

a. Data Primer: data yang diperoleh dari hasil wawancara peneliti dengan narasumber yang langsung memberikan data kepada pengumpul data berupa kegiatan belanja di UPTD Balai Pengujian dan Sertifikasi Mutu Barang Dinas Perindustrian dan Perdagangan Provinsi Sulawesi Utara.

b. Data Sekunder: Data yang didapat dari catatan, buku, majalah berupa laporan keuangan publikasi perusahaan, laporan pemerintah, artikel, buku-buku sebagai teori, majalah, dan lain sebagainya. Sumber yang tidak langsung memberikan data pada pengumpul data. Sujarweni (2014:73).

Sumber data dalam penelitian ini adalah data primer berupa hasil wawancara dengan pimpinan serta pegawai UPTD Balai Pengujian dan Sertifikasi Mutu Barang Dinas Perindustrian dan Perdagangan Provinsi Sulawesi Utara dan data sekunder yaitu berasal dari laporan keuangan publikasi perusahaan. 


\section{Teknik Pengumpulan Data}

Teknik yang digunakan oleh penulis dalam pengumpulan data untukpenelitian ini adalah dengan menggunakan cara sebagai berikut :

1. Penelitian Lapangan (Field Research)

2. Penelitian Kepustakaan (library research)

3. Wawancara(Interview Method)

\section{$4 \quad$ Metode Analisis Data}

Teknik analisis data yang digunakan dalam penelitian ini adalah sebagai berikut :

1. Menganalisis kegiatan pencatatan akuntansi dan pelaporan belanja pada UPTD Balai Pengujian dan Sertifikasi Mutu Barangprovinsi Sulut.

2. Menganalisis belanja pada UPTD Balai Pengujian dan Sertifikasi Mutu Barang provinsi Sulut.

\section{HASIL ANALISIS DAN PEMBAHASAN}

\subsection{Hasil Penelitian}

\subsubsection{Fungsi dan Dokumen Terkait dalam Prosedur Belanja Perjalanan Dinas}

Fungsi-fungsi yang terkait dengan prosedur akuntansi belanja perjalanan dinas baik dalam daerah maupun luar daerah di UPTD Balai Pengujian dan Sertifikasi Mutu Barang Dinas Perindustrian dan Perdagangan Provinsi Sulut adalah :

1. Kuasa Bendahara Umum Daerah (BUD)

2. Pejabat Penatausahaan Keuangan (PPK-SKPD)

3. Pengguna Anggaran/Kuasa Penguna Anggaran. Prosedur Akuntansi Belanja Perjalanan Dinas dalam daerah maupun luar daerah pada UPTD Balai Pengujian dan Sertifikasi Mutu Barang Dinas Perindustrian dan Perdagangan Provinsi Sulut membutuhkan dokumen-dokumen pendukung agar pelaksanaan belanja perjalanan dinas dapat berlangsung. Adapun dokumen-dokumen yang digunakan dalam prosedur belanja perjalanan dinas, yaitu sebagai berikut.

1. Surat Penyediaan Dana (SPD)

2. Surat Permintaan Pembayaran Langsung (SPP-LS)

3. Surat perintah membayar langsung (SPM-LS)

4. Surat Perintah Pencairan Dana (SP2D)

5. Bukti transfer merupakan dokumen atau bukti atas transfer pengeluaran daerah.

6. Nota Debit bank merupakan dokumen atau bukti dari bank yang menunjukan adanya transfer uang dari rekening kas umum daerah.

\subsubsection{Pengakuan Belanja Perjalanan Dinas}

UPTD Balai Pengujian dan Sertifikasi Mutu Barang Dinas Perindustrian dan Perdagangan Provinsi Sulut mengakui belanja perjalanan dinas sebagai belanja langsung dan diakui pada saat pertanggungjawaban atas pengeluaran yang dibuat oleh bendahara pengeluaran telah disahkan oleh kuasa pengguna anggaran, dalam hal ini yaitu kepala UPTD Balai Pengujian dan Sertifikasi Mutu Barang Dinas Perindustrian dan Perdagangan Provinsi Sulut.

\subsubsection{Pengukuran Belanja Perjalanan Dinas}

Pengukuran menggambarkan penentuan besarnya jumlah dalam laporan keuangan.Belanja diakui sebesar jumlah pengeluaran kas yang keluar dari rekening kas umum atau rekening bendahara pengeluaran berdasarkan azas bruto. Menurut Permendagri No 64 Tahun 2013, akuntansi belanja dilaksanakan berdasarkan azas bruto dan diukur berdasarkan nilai nominal yang dikeluarkan dan tercantum dalam dokumen pengeluaran yang 
sah. UPTD Balai Pengujian dan Sertifikasi Mutu Barang Dinas Perindustrian dan Perdagangan Provinsi Sulut telah melaksanakan pengukuran belanja sebesar jumlah pengeluaran kas yang keluar dari rekening kas umum atau rekening bendahara pengeluaran berdasarkan azas bruto dan telah sesuai dengan Permendagri Nomor 64 tahun 2013.

\subsubsection{Prosedur Akuntansi Belanja Perjalanan Dinas}

Prosedur akuntansi Belanja langsung, yaitu serangkaian proses baik manual maupun secara komputerisasi, dimulai dari pencatatan transaksi serta pengikhtisarannya sampai dengan pelaporan keuangan dalam rangka mempertanggungjawabkan pelaksanaan APBD yang terkait dengan Belanja dalam hal ini Belanja Perjalanan Dinas. Sistem dan prosedur belanja perjalanan dinas baik dalam daerah maupun luar daerah yang diterapkan pada UPTD Balai Pengujian dan Sertifikasi Mutu Barang Dinas Perindustrian dan Perdagangan Provinsi Sulut.

\subsubsection{Pelaporan Belanja Perjalanan Dinas berdasarkan Bagan Akun Standar (BAS)}

Pelaporan belanja Perjalanan Dinas pada Laporan Realisasi Anggaran dan Pendapatan pada UPTD Balai Pengujian dan Sertifikasi Mutu Barang Dinas Perindustrian dan Perdagangan Provinsi Sulut dikodifikasi pada nomor rekening.

\subsection{Pembahasan}

4.3.1 Perbandingan Pengakuan Belanja antara Permendagri No. 64 Tahun 2013 dan Penerapan Pengakuan Belanja pada Instansi

Di bawah ini merupakan tabel perbandingan pengakuan belanja antara Permendagri Nomor 64 Tahun 2013 dan penerapan pengakuan belanja pada UPTD Balai Pengujian dan Sertifikasi Mutu Barang Dinas Perindustrian dan Perdagangan Provinsi Sulawesi Utara.

\section{Tabel 4.1 Perbandingan Pengakuan Belanja antara Permendagri 64 Tahun 2013 dan} Penerapan pada Instansi

\begin{tabular}{|c|c|c|c|}
\hline \multirow[b]{2}{*}{$\begin{array}{c}\text { Permendagri No. } 64 \text { Tahun } \\
2013\end{array}$} & \multirow{2}{*}{$\begin{array}{l}\text { Penerapan pada UPTD Balai } \\
\text { Pengujian dan Sertifikasi Mutu } \\
\text { Barang Dinas Perindustrian dan } \\
\text { Perdagangan Provinsi Sulut }\end{array}$} & \multicolumn{2}{|c|}{ Keterangan } \\
\hline & & Sesuai & $\begin{array}{l}\text { Belum } \\
\text { Sesuai }\end{array}$ \\
\hline $\begin{array}{l}\text { Pengakuan belanja terbagi } \\
\text { menjadi dua, yaitu: } \\
\text { 1. Belanja diakui pada saat } \\
\text { terjadinya dari Reke- } \\
\text { ning Kas Umum Da- } \\
\text { erah. } \\
\text { 2. Khusus pengeluaran } \\
\text { melalui bendahara pe- } \\
\text { ngeluaran, pengakuan } \\
\text { terjadi pada saat per- } \\
\text { tanggungjawaban atas } \\
\text { pengeluaran tersebut di- } \\
\text { sahkan oleh pengguna } \\
\text { anggaran. }\end{array}$ & $\begin{array}{l}\text { Mengakui belanja perjalanan dinas } \\
\text { sebagai belanja langsung dan diakui } \\
\text { pada saat pertanggungjawaban atas } \\
\text { pengeluaran yang dibuat oleh } \\
\text { bendahara pengeluaran telah } \\
\text { disahkan oleh kuasa pengguna } \\
\text { anggaran, dalam hal ini yaitu } \\
\text { kepala UPTD Balai Pengujian dan } \\
\text { Sertifikasi Mutu Barang Dinas } \\
\text { Perindustrian dan Perdagangan } \\
\text { Provinsi Sulut }\end{array}$ & $\checkmark$ & \\
\hline
\end{tabular}

Sumber : Data Olahan (2017) 


\subsubsection{Perbandingan Pengukuran Belanja antara Permendagri No. 64 Tahun 2013 dan Penerapan Pengukuran Belanja pada Instansi}

Di bawah ini merupakan tabel perbandingan pengukuran belanja antara Permendagri Nomor 64 Tahun 2013 dan penerapan pengukuran belanja pada UPTD Balai Pengujian dan Sertifikasi Mutu Barang Dinas Perindustrian dan Perdagangan Provinsi Sulawesi Utara.

Tabel 4.2 Perbandingan Pengukuran Belanja antara Permendagri 64 Tahun 2013 dan Penerapan pada Instansi

\begin{tabular}{|l|l|c|c|}
\hline \multirow{2}{*}{$\begin{array}{c}\text { Permendagri No. 64 Tahun } \\
\text { 2013 }\end{array}$} & $\begin{array}{c}\text { Penerapan pada UPTD Balai } \\
\text { Pengujian dan Sertifikasi Mutu } \\
\text { Barang Dinas Perindustrian dan } \\
\text { Perdagangan Provinsi Sulut }\end{array}$ & Sesuai & $\begin{array}{c}\text { Keterangan } \\
\text { Sesuai }\end{array}$ \\
\cline { 2 - 4 } $\begin{array}{l}\text { Akuntansi belanja dilaksa- } \\
\text { nakan berdasarkan azas bruto } \\
\text { dan diukur berdasarkan nilai } \\
\text { nominal yang dikeluarkan } \\
\text { dan tercantum dalam doku- } \\
\text { men pengeluaran yang sah }\end{array}$ & $\begin{array}{l}\text { UPT Balai Pengujian dan Ser- } \\
\text { tifikasi Mutu Barang Dinas Perin- } \\
\text { dustrian dan Perdagangan Provinsi } \\
\text { Sulut telah melaksanakan pengu- } \\
\text { kuran belanja sebesar jumlah pe- } \\
\text { ngeluaran kas yang keluar dari } \\
\text { rekening kas umum atau rekening } \\
\text { bendahara pengeluaran berdasarkan } \\
\text { azas bruto }\end{array}$ & $\checkmark$ & \\
\end{tabular}

Sumber : Data Olahan (2017)

4.3.3 Perbandingan Pelaporan Belanja antara Permendagri No. 64 Tahun 2013 dan Penerapan Pelaporan Belanja pada Instansi

Di bawah ini merupakan tabel perbandingan pelaporan belanja antara Permendagri Nomor 64 Tahun 2013 dan penerapan pelaporan belanja pada UPTD Balai Pengujian dan Sertifikasi Mutu Barang Dinas Perindustrian dan Perdagangan Provinsi Sulawesi Utara. 
Tabel 4.3 Perbandingan Pelaporan Belanja antara Permendagri 64 Tahun 2013 dan Penerapan pada Instansi

\begin{tabular}{|c|c|c|c|}
\hline \multirow[b]{2}{*}{$\begin{array}{c}\text { Permendagri No. } 64 \text { Tahun } \\
2013\end{array}$} & \multirow{2}{*}{$\begin{array}{l}\text { Penerapan pada UPTD Balai } \\
\text { Pengujian dan Sertifikasi } \\
\text { Mutu Barang Dinas } \\
\text { Perindustrian dan } \\
\text { Perdagangan Provinsi Sulut }\end{array}$} & \multicolumn{2}{|c|}{ Keterangan } \\
\hline & & Sesuai & $\begin{array}{l}\text { Belum } \\
\text { Sesuai }\end{array}$ \\
\hline $\begin{array}{l}\text { Klasifikasi belanja yang terlam- } \\
\text { pir dalam lampiran III dibagi } \\
\text { menjadi tiga yaitu: } \\
\text { 1. Belanja Operasi } \\
\text { 2. Belanja Modal } \\
\text { 3. Belanja Lain - Lain / } \\
\text { Belanja Tak terduga } \\
\text { Pengkodifikasian Belanja Perja- } \\
\text { lanan Dinas yaitu dengan nomor } \\
\text { rekening 5.1.2.15 yang terdiri } \\
\text { dari: } \\
\text { 1. Belanja perjalanan dinas } \\
\text { dalam daerah dengan } \\
\text { nomor rekening } \\
\text { 5.1.2.15.01 } \\
\text { 2. Belanja perjalanan dinas } \\
\text { laur daerah dengan nomor } \\
\text { rekening 5.1.2.15.02 } \\
\text { 3. Belanja perjalanan dinas } \\
\text { luar negeri dengan nomor } \\
\text { rekening 5.1.2.15.03 }\end{array}$ & $\begin{array}{l}\text { Pelaporan belanja Perjalanan } \\
\text { Dinas pada Laporan Realisasi } \\
\text { Anggaran dan Pendapatan pada } \\
\text { UPTD Balai Pengujian dan } \\
\text { Sertifikasi Mutu Barang Dinas } \\
\text { Perindustrian dan Perdagangan } \\
\text { Provinsi Sulut dikodifikasi pada } \\
\text { nomor rekening 5.2.2.15 yang } \\
\text { juga terdiri dari : } \\
\text { 1. Belanja Perjalanan Dinas } \\
\text { Dalam Daerah dengan } \\
\text { nomor rekening } \\
\text { 5.2.2.15.01 } \\
\text { 2. Belanja Perjalanan Dinas } \\
\text { Luar Daerah dengan } \\
\text { nomor } \\
\text { 5.2.2.15.02 rekening }\end{array}$ & & $\checkmark$ \\
\hline
\end{tabular}

Sumber : Data Olahan (2017)

\section{KESIMPULAN DAN SARAN \\ 5.1 Kesimpulan}

Kesimpulan yang dapat ditarik dari penelitan ini yaitu:

1. Penerapan belanja pada UPTD Balai Pengujian dan Sertifikasi Mutu Barang Dinas Perindustrian dan Perdagangan Provinsi Sulut diakui pada saat pertanggungjawaban atas pengeluaran yang dibuat oleh bendahara pengeluaran telah disahkan oleh kuasa pengguna anggaran, dalam hal ini yaitu kepala UPTD Balai Pengujian dan Sertifikasi Mutu Barang Dinas Perindustrian dan Perdagangan Provinsi Sulut.

2. UPTD Balai Pengujian dan Sertifikasi Mutu Barang Dinas Perindustrian dan Perdagangan Provinsi Sulut telah melaksanakan pengukuran belanja sebesar jumlah pengeluaran kas yang keluar dari rekening kas umum atau rekening bendahara pengeluaran berdasarkan azas bruto dan telah sesuai dengan Permendagri Nomor 64 tahun 2013.

3. Pengakuan dan pengukuran belanja perjalanan dinas baik dalam daerah maupun luar daerah pada UPTD Balai Pengujian dan Sertifikasi Mutu Barang Dinas Perindustrian dan Perdagangan Provinsi Sulut telah sesuai dengan ketentuan Permendagri Nomor 64 Tahun 2013.

4. Pelaporan belanja perjalanan dinas pada laporan realisasi anggaran dan pendapatan pada UPTD Balai Pengujian dan Sertifikasi Mutu Barang Dinas Perindustrian dan Perdagangan Provinsi Sulut terjadi perbedaan 
5. klasifikasi pencatatannya tetap telah sesuai dengan Permendagri Nomor 64 Tahun 2013 dalam hal penentuan Bagan Akun Standar (BAS).

\subsection{Saran}

Saran dalam penelitian ini yaitu dalam hal pelaporan belanja perjalanan dinas baik dalam daerah maupun luar daerah dalam Laporan Realisasi Anggaran yang belum sesuai pencatatannya dengan klasifikasi belanja pada Bagan Akun Standar (BAS) Permendagri Nomor 64 Tahun 2013, penulis menyarankan kepada UPTD Balai Pengujian dan Sertifikasi Mutu Barang Dinas Perindustrian dan Perdagangan Provinsi Sulut untuk menyesuaikan pengkodifikasian akun belanja perjalanan dinas tersebut sesuai dengan Permendagri Nomor 64 tahun 2013.

\section{DAFTAR PUSTAKA}

Bastian, Indra. 2010. Akuntasi Sektor Publik (Suatu Pengantar Edisi Ketiga). Jakarta. Erlangga.

Bastian, Indra. 2014. Audit Sektor Publik (Pemeriksaan Pertanggungjawaban Pemerintah). Jakarta. Salemba Empat.

Deviani. 2016. "Analisis Belanja Daerah terhadap Pertumbuhan Ekonomi dan Pendidikan

(Studi Empiris Kota dan Kabupaten di Sumatera Barat)”. Pekbis Jurnal, Vol.8, No.1, Hal 1-13.

Erlina, et al.2015. Akuntasi Keuangan Daerah Berbasis Akrual. Jakarta. Salemba Empat

Gramini Media, et al. 2017. "Analisis Kinerja Anggaran Pendapatan Belanja Daerah Kabupaten Morowali Pada Periode Tahun 2011-2015.” Jurnal Ilmu Manajemen Universitas Tadulako, Vol. 3, No. 1, Hal 055-069.

Halim, Abdul dan Kusufi, Muhammad Syam. 2014. Akuntansi Sektor Publik- $\quad$ Akuntansi

Keuangan Daerah. Jakarta. Salemba Empat.

Herry. 2017. Akuntansi Dasar 1 dan 2. Jakarta. Kompas Gramedia.

Katit Fransiskus X.W. dan Pinatik Sherly. 2016. "Analisis Kinerja Belanja Pada Pemerintah Daerah Kabupaten Asmat Provinsi Papua.” Jurnal EMBA, Vol.4 No.3, Hal. 572-582. ISSN 2303-1174.

Karinda Chrisman Youlli. Analisis Kinerja Anggaran Belanja pada Badan Pengelola

Keuangan dan Barang Milik Daerah Provinsi Sulawesi Utara

Liando Grace Yunita dan Elim Inggriani. 2016. "Analisis Kinerja Belanja dalam Laporan

Reaslisasi Anggaran (LRA) pada Dinas Pendapatan Pengelolaan Keuangan dan

Aset Daerah Kabupaten Kepulauan Sangihe." Jurnal $\quad$ EMBA, Vol. 4, No. 1, Hal 1473-1484. ISSN 2303-1174.

Longdong, Arlika S. "Evaluasi Prosedur Pengeluaran Kas Belanja Langsung Pada Dinas Kebersihan Kota Bitung." Jurnal EMBA. Vol.1 No.4, Hal. 383-392. ISSN 2303-1174.

Lontaan Indra Christian dan Pangerapan Sony. 2016. "Analisis Belanja Daerah pada Pemerintah Kabupaten Minahasa Tahun Anggaran 2012-2014.” $\quad$ Jurnal EMBA. Vol.4 No.1, Hal. 898-906. ISSN 2303-1174. 